\title{
DEMOKRASI DAN TRANSPARANSI PARTAI KEBANGKITAN BANGSA DALAM REKRUTMEN CALEG PADA PEMILU 2019
}

\author{
Muhammad Ruslan1, Eusabius Separera Niron² \\ ${ }^{1}$ Fakultas Ilmu Sosial dan Politik, Universitas Airlangga Surabaya \\ Korespondensi email: mruslan831@gmail.com \\ ${ }^{2}$ Fakultas Ilmu Sosial dan Politik, Universitas Airlangga Surabaya \\ email: esthonniron@gmail.com
}

\begin{abstract}
This article aims to take photos and browse in critical problems of democracy and transparency of the Kebangkitan Bangsa Party in the recruitment of candidates in the 2019 elections. The recruitment process in political parties includes three stages, namely certification, nomination, and election. Through qualitative research with analytical-critical description method, this paper argues that the mechanism of political recruitment in the Kebangkitan Bangsa Party through an undemocratic and untransparent process, where prospective legislative candidates who register to become prospective legislative candidates only submit registration forms and various completeness of the other files and henceforth the prospective candidates are only waiting for the process of determining the serial number of candidate by the leadership of political parties. In addition, the position number is determined without going through the readiness and competency test mechanism of the candidates.
\end{abstract}

Keyword: political parties; democracy; transparency; 2019 elections.

\begin{abstract}
ABSTRAK
Artikel ini bertujuan untuk memotret dan menelisik secara kritis problem demokrasi dan transparansi Partai Kebangkitan Bangsa dalam rekrutmen caleg pada pemilu 2019. Proses rekrutmen dalam partai politik meliputi tiga tahap yaitu sertifikasi, nominasi, dan pemilihan. Melalui penelitian kualitatif dengan metode deskripsi analitis-kritis, tulisan ini berargumen bahwa mekanisme rekrutmen politik di Partai Kebangkitan Bangsa melalui proses yang tidak demokratis dan tidak transparan, dimana bakal calon anggota legislatif yang mendaftar untuk menjadi bakal calon anggota legislatif hanya menyerahkan formulir pendaftaran dan berbagai kelengkapan berkas lainnya dan untuk selanjutnya para bakal calon hanya menunggu proses penetapan nomor urut calon oleh pimpinan partai politik. Selain itu juga posisi nomor urut ditentukan tanpa melalui mekanisme uji kesiapan dan kompetensi calon legislatif.
\end{abstract}

Kata Kunci: partai politik; demokrasi; transparansi; pemilu 2019.

\section{PENDAHULUAN}

Diskursus soal eksistensi partai politik di Indonesia sesungguhnya menarik perhatian publik. Partai politik berperan strategis dalam menyalurkan dan memperjuangkan kepentingan masyarakat dalam sebuah sistem politik demokratis. Selain itu juga kedudukan parpol sangat strategis karena merupakan satu-satunya institusi 
demokrasi yang menjalankan fungsi rekrutmen politik. Seperti diamanatkan oleh UUD 1945 hasil amandemen, parpol adalah peserta pemilu legislatif untuk memilih anggota DPR dan DPRD, dan pengusung pasangan calon dalam pemilihan presiden dan wapres (pilpres). Dalam perkembangannya kemudian, melalui undang-undang yang disepakati bersama oleh DPR dan Presiden, parpol juga merupakan pengusung pasangan calon dalam pemilihan kepala daerah (pilkada) untuk memilih gubernur, bupati, dan walikota berikut para wakilnya. Disamping itu, parpol melalui DPR, adalah penentu akhir seleksi hampir semua jabatan publik, baik anggota maupun pimpinan komisi-komisi Negara (Haris et al., 2018).

Namun, realitas politik kontemporer menunjukan dengan jelas bahwa kehadiran parpol di Indonesia tidak otomatis berkontribusi positif terhadap sistem politik yang demokratis pula. Robert Michels, menyatakan bahwa organisasi politik yang berskala besar seperti partai politik, cenderung dikelola secara oligarkis yang lebih melayani kepentingan sendiri daripada kepentingan organisasi (Haris, 2006) (Bariroh, 2015).

Keberadaan dan perkembangan partai politik di Indonesia pasca reformasi belum menunjukan eksistensi sebagai sebuah institusi publik yang memiliki tanggung jawab terhadap masyarakat pemilihnya. Partai politik seakan-akan kaget dengan tuntutan masyarakat yang besar namun tidak disertai dengan kelembagaan yang baik. Partai politik dewasa ini belum memperlihatkan akuntabilitas, transparansi dan demokrasi baik kepada konstituen maupun anggota atau kadernya (Manar, 2016) (Romli, 2011).

Menurut pandangan Sulaeman (2015), partai politik pada era reformasi juga terjebak dalam bentuk oligarkis dalam proses pengambilan keputusan strategis. Kecenderungan selama ini menunjukkan pengambilan keputusan partai politik bersifat tertutup dan hanya ditentukan oleh sekelompok kecil elit partai. Keputusan tertinggi biasanya berada pada seseorang atau sekelompok kecil elit partai saja. Persoalan mekanisme internal dalam pembuatan keputusan dicirikan dengan sentralisasi dalam pengambilan keputusan. Peran pengurus pusat masih dominan, dan terkadang berbeda dengan aspirasi daerah. Selain itu, jika digunakan parameter "personalisasi" ini untuk menilai kondisi partai-partai politik di tanah air dewasa ini, tentu banyak sekali partai politik belum melembaga secara depersonalized. Alhasil, partai politik tidak benar-benar menjaring aspirasi dari bawah tentang calon yang diharapkan masyarakat, melainkan berdasarkan kepentingan pragmatis sekelompok elit saja. Padahal personalisasi partai politik merupakan salah satu masalah yang dapat mencederai konsolidasi demokrasi yang sedang dibangun.

Dalam konteks pelaksanaan fungsi partai politik memperlihatkan bahwa ada problem serius dimana partai politik belum melaksanakan fungsinya secara maksimal. Sumber masalah dari belum terlaksananya fungsi partai politik tersebut adalah terkait dengan persoalan pelembagaan partai politik di Indonesia, salah satunya yakni rekrutmen politik (Romli et al., 2008). Salah satu faktor yang menyebabkan produk dan mekanisme rekrutmen politik yang buruk ini adalah belum terbangunnya sistem rekrutmen politik yang baku, terbuka, demokratis, dan akuntabel parpol di Indonesia. Sebagian parpol mendasarkan sumber rekrutmen politik dari lingkungan keluarga dan kerabat politik para elite parpol itu sendiri, sehingga cenderung berlangsung tertutup, eksklusif, dan nepotis. Meskipun ada prosedur formal yang dimiliki parpol dalam proses rekrutmen, namun dalam realitasnya prosedur tersebut tidak sepenuhnya diimplementasikan oleh pimpinan parpol (Haris et al., 2018).

Hasil riset yang pernah dilakukan LIPI menjelang Pemilu 2004, misalnya, memperlihatkan bahwa meski sebagian parpol memiliki prosedur seleksi calon anggota legislatif yang baku, namun justru pimpinan parpol sendiri yang sering melanggar prosedur seleksi kandidat yang telah disepakati bersama tersebut. Jadi, meskipun ada 
prosedur baku yang dimiliki parpol dalam seleksi kandidat legislatif, namun seringkali prosedur tersebut berhenti sebagai dokumen tertulis belaka. Sementara itu, problem lain terkait rekrutmen calon pejabat publik adalah relatif belum terlibatnya anggota partai dalam seleksi kandidat, baik untuk pileg maupun untuk pasangan calon dalam pilpres dan pilkada (Haris et al., 2018).

Pola rekrutmen dan seleksi anggota legislatif (DPR dan DPRD) memang menjadi otoritas partai politik. Meski demikian, jika merujuk pada ketentuan yang ada baik UndangUndang No. 2 Tahun 2011 tentang Partai Politik dan Undang-Undang No. 7 Tahun 2017 tentang Pemilu, menyebutkan bahwa seleksi calon legislatif dilakukan secara demokrtasi dan terbuka sesuai dengan anggaran dasar, anggaran rumah tangga, dan/atau peraturan internal partai. Dalam hal ini sebetulnya terdapat dua indikator yang perlu diperhatikan dalam seleksi calon yang patut diperhatikan oleh partai yakni "demokratis" dan "terbuka". Namun sayangnya ketentuan ini tidak menjabarkan secara lebih spesifik indikator dari seleksi calon yang demokratis dan terbuka seperti apa. Sehingga sejauh ini proses seleksi calon masih menjadi urusan dapur partai (Waskita et al., 2016).

Problematika dalam tahapan pencalonan calon legislatif oleh partai politik selama ini berlangsung secara tertutup, tidak transparan dan hanya melibatkan elit parpol. Partai politik tidak menyuguhkan informasi yang cukup mengenai metode rekrutmen dan seleksi calon anggota legislatif kepada masyarakat (Syamsuadi \& Yahya, 2018). Tiba-tiba saja nama-nama calon legislatif itu terpampang di daftar calon yang ditetapkan KPU. Tidak ada transparansi dalam mekanisme rekrutmen calon anggota legislatif yang dilakukan oleh partai politik. Namun Undang-Undang Nomor 7 Tahun 2017 berbeda, Pasal 241 mensyaratkan pelaksanaan seleksi bakal calon legislatif yang demokratis dan terbuka sesuai dengan AD/ART partai politik (Solihah, 2018).

Lebih lanjut Solihah (2018), menjelaskan bahwa tertutupnya informasi mengenai rekrutmen dan seleksi bakal calon legislatif oleh partai politik membuat publik tidak banyak mengetahui mengenai bagaimana partai politik itu bekerja dalam merekrut dan menyeleksi kandidatnya. Bagaimana partai politik mengkaderkan anggotanya untuk diikutkan dalam pencalonan anggota legislatif yang akan menduduki jabatan politik dalam pemerintahan, baik eksekutif maupun legislatif. Padahal pemilihan caleg yang akan diikutsertakan dalam Pemilu 2019, diwajibkan menggunakan proses rekrutmen terbuka sesuai AD/ART masing-masing parpol.

Artikel ini membahas tentang persoalan demokrasi dan transparansi Partai Kebangkitan Bangsa (PKB) dalam rekrutmen Caleg pada Pemilu 2019. Ada dua permasalah utama dalam tulisan ini. Pertama, bagaimana proses rekrutmen politik Partai Kebangkitan Bangsa (PKB) dalam Pemilu 2019? Kedua, apakah proses rekruitmen politik caleg Partai Kebangkitan Bangsa (PKB) di Dapil Jatim 11 dalam Pemilu 2019 itu berlangsung secara demokratis dan transparan?

\section{TINJAUAN PUSTAKA}

Rekrutmen politik merupakan salah satu fungsi penting dan strategis parpol yang tidak hanya menentukan kualitas wakil rakyat dan para pejabat publik yang diproduksi oleh parpol melalui pemilihan umum, tetapi juga turut mempengaruhi kualitas sistem demokrasi itu sendiri. Begitu pentingnya fungsi rekrutmen politik ini bagi parpol sehingga fungsi-fungsi parpol lainnya menjadi kurang bermakna jika parpol gagal dalam menjalankan fungsi rekrutmen politik.

Heywood (2014), memberikan defenisi rekrutmen politik sebagai pemilihan primer merupakan sebuah pemilihan intra partai, dimana para kandidat diseleksi untuk mewakili partai maju kesebuah pemilihan resmi yang akan berlangsung. Menurut Surbakti (2010), 
rekrutmen politik sebagai seleksi dan pemilihan atau seleksi pengangkatan seseorang atau sekelompok orang untuk melaksanakan sejumlah peranan dalam sistem politik pada umumnya dan pemerintahan pada khususnya. Selain itu, secara khusus dalam konteks politik rekrutmen politik sering merujuk pada seleksi kandidat (kandidasi), rekrutmen legislatif dan eksekutif (Pamungkas, 2011).

Rekrutmen politik dibagi menjadi dua kategori yaitu, rekrutmen yang bersifat umum yaitu proses dimana individu atau kelompok-kelompok individu dilibatkan dalam peran politik aktif. Rekrutmen secara khusus yaitu seleksi kandidat (kandidasi), dalam hal ini terkait rekrutmen untuk jabatan legislatif dan eksekutif. Seleksi kandidat merupakan tahap kunci yang menentukan orang-orang yang akan menjadi wakil rakyat dan yang akan memerintah (Haris et al., 2018).

Seleksi kandidat merupakan salah satu fungsi utama dan khas dari partai politik dalam sistem politik demokrasi. Hal ini tidak hanya karena seleksi kandidat untuk bersaing pada pemilihan umum merupakan salah satu fungsi yang membedakan partai politik dari organisasi lain yang mungkin berupaya mempengaruhi hasil pemilihan umum dan keputusan yang akan diambil pemerintah. Kekhasan fungsi itu juga karena kandidat yang dinominasikan memainkan peran penting dalam menentukan karakteristik partai politik yang bersangkutan di mata publik. Oleh karena itu, partisipasi anggota partai dalam penentuan kandidat merupakan suatu keharusan (Haboddin, 2019).

Selanjutnya, Hazan dan Rahat memandang bahwa metode seleksi kandidat merupakan komponen penting dalam demokrasi partai secara internal. Pertama, kandidat merupakan salah satu aktor utama yang menentukan arah kegiatan partai politik sehingga perlu diidentifikasi posisi kekuasaan dalam partai dan bagaimana kekuasaan itu digunakan. Kedua, seleksi kandidat juga merupakan komponen utama untuk memahami evolusi berbagai model organisasi partai yang berbeda. Ketiga, seleksi kandidat juga mempengaruhi faktor luar partai, yaitu pilihan yang dihadapi pemilih, komposisi badan legislatif, kekompakan fraksi-fraksi di parlemen, kepentingan yang menonjol dalam perdebatan kebijakan, dan produk legislatif yang dihasilkan (Surbakti \& Supriyanto, 2013).

Skema dan proses rekruitmen politik meliputi tahap penting, yaitu: Pertama tahap sertifikasi merupakan tahap awal atau pendefenisian, yang antara lain mencakup penentuan kriteria yang dikehendaki, aturan internal partai, aturan pemilihan, dan normanorma sosial. Sertifikasi diantaranya berisi mengenai persyaratan yang didasarkan pada hukum yang berlaku atau yang diatur oleh undang-undang. Aturan tersebut berkaitan dengan persyaratan individu seperti usia minimum, kewarganegaraan, deposito uang, dan lain-lain. Selain persyaratan yang diatur oleh hukum, partai biasanya juga memiliki persyaratan sertifikasi yang telah disepakati oleh internal partai. Persyaratan tersebut biasanya berkaitan dengan hubungan individu dengan partai seperti batas minimal waktu individu bergabung dengan partai. Hal tersebut dilakukan partai supaya dapat mengukur loyalitas hubungan antara "yang akan dicalonkan" dengan partai. Akan tetapi, persyaratan partai tidak selalu tentang jangka waktu bergabung, hal tersebut tergantung dengan apa yang disepakati dalam internal partai (Sianturi, 2015).

Kedua, tahap nominasi terkait dengan ketersediaan calon untuk dinominasikan dan proses dimana penyeleksi calon menentukan siapa yang akan dicalonkan dalam Pemilu. Peran partai politik dalam proses nominasi, yaitu (1) mencalonkan kandidat di dalam proses pemilu; (2) memberikan jaringan sosial (konstituen dan elemen pendukung lainnya); (3) Training dan pelatihan peningkatan kapasitas; (4) pengalaman organisasi berpartai yang meningkatkan kapasitas dalam pembuatan kebijakan dan lainnya. Beberapa hal penting dalam proses nominasi, yaitu (1) Derajat sentralisasi partai, berbicara tentang pencalonan kandidat ditentukan secara bertahap mulai dari elit partai di tingkat pusat 
(top-down) ke tingkat dibawahnya atau dari elit daerah ke level diatasnya (bottom-up); (2) kedalaman partisipasi, apakah proses penetapan calon dilakukan oleh sedikit elit atau banyak elit; (3) Jumlah orang yang akan dicalonkan, yakni apakah hanya ada satu calon tunggal, beberapa atau banyak calon untuk dipilih sebagai kandidat pemilu. Ketiga, pemilihan berkaitan dengan bagaimana cara memilih, siapa yang dilibatkan untuk memilih, dan bagaimana cara menentukan siapa yang akan menang.

Ketiga, tahap pemilu adalah langkah terakhir dimana kandidat memenangkan jabatan publik. Sistem pemilu sebagai aturan permainan dalam tahap akhir rekrutmen pejabat publik dan anggota parlemen yakni: majoritarian, proporsional dan campuran. Sedangkan kebijakan lain dalam pemilu yang terkait dengan rekrutmen yakni: reserved seat dan kuota (Haris et al., 2018).

Pola rekrutmen politik terbentuk atas hubungan antara ketersediaan kandidat yang mencari karir politik dan proses seleksi yang ditetapkan oleh partai politik. Terdapat dua pola rekrutmen partai politik yaitu, pola vertikal dan pola lateral. Pertama, pola vertikal merupakan proses rekrutmen partai dilakukan secara hirarki dengan jalur struktural dalam organisasi partai. Dalam pola ini, organisasi partai memiliki kekuasaan dalam menentukan siapa kandidat yang tepat untuk mengisi jabatan politik (Haris et al., 2016). Partai dalam memilih kandidat berdasarkan pertimbangan: (1) kader partai yang bekerja sudah lama; (2) kemampuan politik seseorang; (3) rekrutmen terhubung dengan jenjang karir organisasi (merit sistem) yang ditentukan atas dasar prestasi atau kinerja kader. Merit sistem adalah sebuah proses rekrutmen yang didasarkan pada jenjang kaderisasi yang telah baku diterapkan pada suatu organisasi partai. Kedua, pola lateral yaitu rekrutmen dibuka kepada semua individu baik di dalam partai maupun di luar partai. Kader baru dapat masuk menjadi kandidat untuk menantang para petahana atau kader-kader senior yang telah lama berkecimpung di partai. Pola ini menekankan pada bekerjanya sistem organisasi partai secara demokratis, yang salah satunya dicirikan oleh kekuasaan yang terdesentralisasi (Haris et al., 2018).

\section{METODE}

Artikel ini ditulis dengan menggunakan pendekatan kualitatif dengan metode deskripsi analitis-kritis. Penelitian kualitatif merupakan penelitian yang bersifat interpretatif (menggunakan penafsiran) yang melibatkan banyak metode, dalam menelaah masalah penelitian (Mulyana \& Solatun, 2007). Sebagai penelitian berjenis kualitatif, penelitian ini dilakukan dengan cara menginterpretasikan masalah demokrasi dan transparansi Partai Kebangkitan Bangsa (PKB) dalam rekrutmen Caleg pada Pemilu 2019, berdasarkan data-data yang diperoleh dari wawancara mendalam dan studi dokumen.Analisis data menggunakan perspektif teori rekrutmen politik.

\section{HASIL DAN PEMBAHASAN}

Rekrutmen politik merupakan salah satu fungsi partai politik dalam mengisi jabatan-jabatan dalam sistem pemerintahan. Untuk mengisi jabatan tersebut, partai politik berkompetisi dalam pemilihan umum dalam rangka memperebutkan jabatan publik baik eksekutif maupun legislatif.

Partai politik dalam melakukan rekrutmen berpedoman kepada sejumlah prinsip, yaitu: (1) loyalitas, merupakan landasan penting bagi seorang politisi untuk bersikap dan bertindak sesuai ideologi partai; (2) bersih, bersih dari tindakan tercela, baik dari norma sosial, agama, maupun kepentingan sosial; (3) transparan/terbuka, prinsip transparan diterapkan dalam proses rekrutmen, transparan terhadap profil politisi dan partai politik, serta kapasitas politisi baik dari segi kualitas pendidikan maupun kemampuan ekonomi; 
(4) akuntabilitas, rekrutmen politik dapat dipertanggungjawabkan baik kepada anggota maupun kepada masyarakat; (5) meritokrasi, rekrutmen politik mengesampingkan kedekatan keluarga, personal, dan kultural. Yang idealnya adalah rekrutmen dilakukan berdasarkan keahlian, kecakapan teknis dan pengalaman organisasi; (6) demokratis (fairness dan inklusif), proses rekrutmen dengan melibatkan partisipasi semua anggota, rekrutmen bukan hanya dilakukan oleh segelintir elit akan tetapi melibatkan semua anggota dalam proses nominasi; (7) decentralized/autonomus, pola penentuan caleg oleh pengurus partai tingkat pusat maupun daerah dilakukan secara proporsional; (8) kecukupan pembiayaan (financial-sufficiency), dalam melakukan rekrutmen partai politik memperhatikan kemampuan finansial calon anggota partai atau caleg untuk pembiayaan dana kampanye; (9) Humanis, rekrutmen ditujukan kepada siapa saja tanpa dengan mengabaikan status sosial-ekonomi; (10) non-partisan, berlaku kepada tim seleksi bahwa dalam melakukan rekrutmen harus memposisikan calon dengan hak yang sama, penyeleksi tidak diskriminatif kepada calon tertentu dan sebaliknya tidak istimewa kepada calon tertentu (Haris et al., 2018).

Berdasarkan wawancara dengan salah satu calon anggota legislatif (caleg) DPR RI Partai Kebangkitan Bangsa daerah pemilihan Jawa Timur 11 (sebelas) yang meliputi Kabupaten Bangkalan, Kabupaten Sampang, Kabupaten Pamekasan, dan Kabupaten Sumenep. Dapil Jatim 11 ini memiliki alokasi kursi sebanyak 8 (delapan), caleg tersebut menjelaskan bahwa proses rekrutmen sebagai berikut: Pertama, proses pendaftaran bakal calon anggota legislatif dibuka secara umum baik untuk kader partai maupun yang bukan kader dengan ketentuan memenuhi syarat sesuai dengan peraturan perundang-undangan. Selanjutnya pendaftar menyerahkan formulir pendaftaran caleg di Dewan Pimpinan Cabang PKB. Ada masalah dalam proses penyerahan formulir terkait tempat penerimaan formulir yang diserahkan oleh Caleg. Dimana, ada salah satu Caleg yang tidak menyerahkan lewat DPC PKB melainkan menyerahkan formulir lewat DPW PKB. Dimana informasi yang diterima adalah penyerahan dilakukan di kantor DPC PKB Dapil Jatim 11. Ketidakseragaman tempat penyerahan formulir pendaftaran calon di internal partai ini menuai kecurigaan adanya praktek oligarki.

Kedua, pengurus partai menyerahkan Kartu Tanda Anggota (KTA) partai pada saat setelah penyetoran formulir pendaftaran bagi pendaftar umum yang bukan kader partai. Selanjutnya adalah otoritas partai yang menentukan nomor urut bakal calon anggota legislatif (bacaleg). Penentuan nomor urut dalam susunan bakal calon anggota legislatif dilakukan secara tertutup, dimana para bacaleg tidak mengetahui proses yang yang terjadi didalam sampai dengan penetapan susunan nomor urut. Menurut keterangan informan bahwa dia ditempatkan nomor urut tiga karena latar belakang pendidikan sebagai sarjana Ilmu Politik dan sedang menempuh studi magister ilmu politik. Menurut pendapat informan bahwa penetapan susunan nomor urut berdasarkan keterangan dari pengurus DPC PKB adalah berdasarkan kader senior menempati nomor urut tertinggi. Akan tetapi, caleg nomor urut 1 diketahui bukan kader senior PKB, melainkan anggota Partai Persatuan Pembangunan (PPP) yang pernah menjadi caleg pada Pemilihan Umum Tahun 2014 yang dicalonkan oleh PPP. Selain itu, caleg nomor urut 1 (satu) tersebut, tidak berdomisili di Dapil 11 melainkan berdomisili di Depok Jawa Barat.

Selain itu jika ditelusuri secara detail terkait data dan informasi seleksi bakal calon anggota legislatif (bacaleg) Pemilu 2019 dari Partai Kebangkatan Bangsa (PKB), maka Informasi mengenai seleksi bacaleg PKB sulit ditemukan dalam website resmi PKB http://pkb.or.id/. Halaman awal website PKB hanya menampilkan berita kegiatan harian PKB. Tidak ada menu khusus mengenai informasi pendaftaran bacaleg Pemilu 2019. Fasilitas pencarian dalam website inipun tidak memberikan jawaban ketersedian informasi 
seleksi bacaleg. Dalam website ini juga tidak ada dokumen AD/ART yang dapat diakses masyarakat. Informasi bahkan formulir pendaftaran seleksi caleg justru dapat diperoleh di laman google melalui alamat website PKB Kalteng.

Partai Kebangkitan Bangsa (PKB) sebagai salah peserta Pemilu 2019 memang memiliki website dalam rangka memperluas akses informasi bagi kader partai dan masyarakat umum, namun website tersebut belum memuat data dan informasi yang lengkap tentang, AD/ART Partai, pedoman pendaftaran dan mengikuti seleksi bacaleg dalam pemilu 2019. Hal ini juga terjadi karena aturan UU maupun PKPU tentang kewajiban partai politik melaksanakan seleksi bacaleg secara demokratis dan terbuka tidak didukung dengan rincian aturan yang lebih jelas. Regulasi yang ada justru menyerahkan mekanisme seleksi demokratis dan terbuka tersebut sesuai dengan AD/ART masing-masing partai politik. Bahkan tidak ada kewajiban bagi partai politik untuk melaporkan atau melampirkan mekanisme rekrutmen dan seleksi bacaleg tersebut kepada KPU sebagai bukti telah melaksanakan kewajiban yang diatur dalam UU dan PKPU.

Berdasarkan data-data tersebut diatas, maka dapat dikatakan bahwa proses rekrutmen politik bakal calon anggota legislatif di PKB, belum memenuhi prinsip rekrutmen yang demokratis dan transparan, karena ada kecenderungan dalam menetapkan susunan nomor urut calon berdasarkan kedekatan personal, kemampuan finansial ketimbang orang-orang yang kompeten dan memiliki kapasitas, terbukti dengan penetapan nomor urut satu dalam susunan bakal calon anggota legislatif PKB yang bukan kader partai senior, dimana kader senior ditempatkan pada nomor urut dua. Selain itu tidak terdapatnya pola persaingan yang sehat dalam proses rekrutmen. Seharusnya proses rekrutmen transparan dalam tahapan nominasi sampai dengan tahapan penetapan, dalam hal ini pasca pendaftaran harus diketahui oleh peserta berapa jumlah pendaftar, apakah sudah memenuhi kuota sebanyak 8 (delapan) orang. Idealnya pada tahap nominasi partai politik menetapkan 2 (dua) kali jumlah bakal calon anggota legislatif, yaitu sebanyak 16 orang yang selanjutnya akan dipilih dan ditetapkan oleh tim seleksi internal partai politik sebanyak 8 (delapan) orang. Namun, yang terjadi adalah para pendaftar hanya menyerahkan formulir dan tidak mengetahui tahapan rekrutmen. Para pendaftar hanya menunggu namanya ditetapkan dalam susunan nomor urut bakal calon anggota legislatif.

\section{KESIMPULAN}

Partai politik merupakan mesin politik yang diorganisasikan untuk memenangkan kontestasi politik elektoral dalam rangka meraih kekuasaan dalam lembaga eksekutif dan legislatif. Untuk dapat mewujudkan cita-cita politik tersebut, partai politik memerlukan calon yang berkualitas. Calon yang yang berkualitas bersumber dari proses rekrutmen yang demokratis dan transparan yaitu adanya kerangka aturan internal partai yang jelas, mengikat, dan dapat dilaksanakan dalam proses sertifikasi, nominasi, dan pemilihan. Aturan yang jelas mengenai rekrutmen tersebut misalnya, dimuatnya syarat pendidikan, rekam jejak terkait dengan integritas, uji kompetensi (fit and propertest) terkait pengalaman organisasi dan pengetahuan tentang tugas dan fungsi anggota DPR.

\section{DAFTAR RUJUKAN}

Bariroh, L. (2015). Positioning Ideologi Partai Politik Pada Preferensi Politik Santri. Jurnal Review Politik, $4(1)$,

133-164. http://jurnalpolitik.uinsby.ac.id/index.php/jrp/article/view/48

Haboddin, M. (2019). Populisme, Politik Pertahanan, dan Pemimpin Lokal. Jurnal Inovasi Ilmu Sosial Dan Politik (JISoP), 1(2), 173-180. https://doi.org/10.33474/jisop.v1i2.4802 
Haris, S. (2006). Demokratisasi partai dan dilema sistem kepartaian di indonesia. Jurnal Penelitian Politik, 3(1), 2006. https://doi.org/10.14203/jpp.v3i1.537

Haris, S., Bhakti, I. N., Nurhasim, M., Nuryanti, S., Yanuarti, S., Tryatmoko, M. W., Gayatri, I. H., Kartini, I., Siregar, S. N., \& Budiatri, A. P. (2016). Panduan Rekrutmen \& Kaderisasi Partai Politik Ideal di Indonesia. Direktorat Pendidikan dan Pelayanan Masyarakat Kedeputian Pencegahan, Komisi Pemberantasan Korupsi Bekerja sama dengan Pusat Penelitian Politik, Lembaga Ilmu Pengetahuan Indonesia (P2Politik LIPI).

Haris, S., Nurhasim, M., Nuryanti, S., Yanuarti, S., \& Seftiani, S. (2018). Sistem Integritas Partai Politik. In P. Nainggolan, G. Suprapdiono, Sujanarko, G. Kusmeiyano, D. Rustandi, D. Sepriwasa, A. Nurlitasari, Kristiyanti, \& Y. T. Lestari (Eds.), Naskah Kertas Posisi (Position Paper) (2nd ed., pp. 1-42). Direktorat Pendidikan dan Pelayanan Masyarakat, Kedeputian Pencegahan, Komisi Pemberantasan Korupsi Bekerja sama dengan Pusat Penelitian Politik, Lembaga Ilmu Pengetahuan Indonesia. https://acch.kpk.go.id/id/berkas/buku-antikorupsi/umum/sistemintegritas-partai-politik-sipp

Heywood, A. (2014). Politik (4th ed.). Pustaka Pelajar.

Manar, D. G. (2016). Akuntabilitas Partai Politik di Kota Semarang: Kajian Pelaksanaan Akuntabilitas Pada Partai Demokrat Di Kota Semarang Tahun 2009-2014. JIIP: Jurnal Ilmiah Ilmu Pemerintahan, 2(1), 8-18. https://doi.org/10.14710/jiip.v2i1.1705

Mulyana, D., \& Solatun. (2007). Metode Penelitian Komunikasi (1st ed.). Remaja Rosdakarya. Pamungkas, S. (2011). Partai Politik: Teori dan Praktik di Indonesia. Institute for Democracy and Welfarism.

Romli, L. (2011). Reformasi Partai Politik dan Pistem Kepartaian di Indonesia. Jurnal Politica, 2(2), 199-220. https://doi.org/10.22212/jp.v2i2.292

Romli, L., Perdana, A., Ichwanuddin, W., \& Sabri, M. N. (2008). Kerangka Penguatan Partai Politik. Puskapol FISIP UI.

Sianturi, K. A. (2015). Memperkuat Fungsi Rekrutmen Partai Politik (Strengthening The Recruitment Function Of Political Party). Jurnal Legislasi Indonesia, 12(1), 1-22. http://e-jurnal.peraturan.go.id/index.php/jli/article/view/369

Solihah, R. (2018). Peluang dan tantangan pemilu serentak 2019 dalam perspektif politik. Jurnal Ilmiah Ilmu Pemerintahan, 3(1), 73-88. https://doi.org/10.14710/jiip.v3i1.3234

Sulaeman, A. (2015). Demokrasi, Partai Politik Dan Pemilihan Kepala Daerah. CosmoGov, 1(1), 12-24. https://doi.org/10.24198/cosmogov.v1i1.11857

Surbakti, R. (2010). Memahami Ilmu Politik. Grasindo.

Surbakti, R., \& Supriyanto, D. (2013). Mendorong Demokratisasi Internal Partai Politik (S. Pramono (ed.)). Kemitraan bagi Pembaruan Tata Pemerintahan.

Syamsuadi, A., \& Yahya, M. R. (2018). Model Kandidasi Birokrat Oleh Partai Politik Pada Pemilihan Kepala Daerah Langsung Di Kabupaten Rokan Hilir Tahun 2015. Journal of Governance, 3(2), 133-153. https://doi.org/10.31506/jog.v3i2.3868

Waskita, O. S. L., Asy'ari, A. H., \& A.L.W, L. T. (2016). Optimalisasi Tata Cara Partai Politik Dalam Rekrutmen Calon Anggota Dewan Perwakilan Rakyat Untuk Mewujudkan Pemerintahan Yang Baik (Good Governance) Berdasarkan Undang-Undang Nomor 8 Tahun 2012. Dipenogoro Low Journal, 5(4), 1-13. https://ejournal3.undip.ac.id/index.php/dlr/article/view/13298 